\title{
- Master Narratives/Servant Texts: Representing the Maid from Flaubert to Freud
}

In a celebrated scene from Mirbeau's Le Journal d'une femme de chambre (Diary of a Chambermaid [1901]), so of ten cited as a paradigmatic example of foot fetishism, the specific nature of the fetish object itself is at first far from clear.

- Ainsi, cela ne vous déplaît pas que je vous appelle Marie?... C'est bien entendu?...

-Mais oui, Monsieur...

Jolie fille... bon caractère... Bien, bien!

Il m'avait dit tout cela d'un air enjoué, extrêmement respectueux, et sans me dévisager, sans fouiller d'un regard déshabilleur mon corsage, mes jupes, comme font, en 'général, les hommes. A peine sil m'avait regardée. Depuis le moment où il était entré dans le salon, ses yeux restaient obstinément fixés sur mes bottines.

-Vous en avez d'autres? ... me demanda-t-il, après un court silence, pendant lequel il me sembla que son regard était devenu étrangement brillant.

-D'autres noms, Monsieur?

- Non, mon enfant, d'autres bottines...

Et il passa sur ses lèvres, à petits coups, une langue effilée, à la manière des chattes.

Je ne répondis pas tout de suite. Ce mot de bottines, qui me rappelait l'expression de gouaille polissonne du cocher, m'avait interdite. Cela avait donc un sens?

- "You don't mind then if I call you Marie, it's understood?"

"Of course, Monsieur."

176 
"Pretty girl, good character. Very good indeed."

He had said all this to me with a playful, extremely respectful air, without a look that undresses you, like most men give. From the moment he walked into the salon, his eyes remained obstinately fixed on my boots.

"You have others?" he asked me, after a short silence, during which it seemed to me that his gaze became peculiarly brilliant.

"Other names, Monsieur?"

"No, my child, other boots."

And he passed his tapered tongue quickly over his lips like a cat.

I didn't answer right away. The word boots, reminding me of the vulgar wisecracks of the coachman, struck me dumb. Did it mean something? ${ }^{1}$

A deliberate confusion in the ascription of names to things generates an initial uncertainty as to what precisely might be the object of Monsieur Rabour's fetishistic vision. On the level of possible substitutions the alternatives are at least threefold: "Célestine," the personal first name of the maid, has been exchanged for "others" (d'autres), that is, other more impersonal and conventionally attributed maids' names such as "Marie" or "Rose." In this simple operation the maid loses her individuality and assumes the institutional nonidentity of the domestic. Second, if one follows the obsessional and exclusive direction of the master's gaze, a metonymic article of her traditional uniform has been substituted for the maid herself. The boot, visually detached from the rest of her body, stands in as the sign of her sexual role, more important than the directly accessible but less fetishistic blouse. Like the apron, another object of desire in classic scenarios of sexual fantasy, the boot operates as a casing, or cache-sexe, for the invisible feminine phallus, acquiring through contiguity a value as a substitution for a substitution. A double metonymy then, or is it in fact triple? For it is not just the boot, symbolizing the missing phallus or the missing identity of the maid, but also the name of the boot-"ce mot de bottine"- that in itself refers to a wide circumference of pathologies characterizing the rapport between master and servant in the turn-of-the-century bourgeois household.

As an exemplary description of foot fetishism, this episode of Mirbeau's novel, written prior to Freud's theory, conforms virtually

1. Octave Mirbeau, Le Journal d'une femme de chambre (Paris: Garnier-Flammarion, 1983), p. 38. Further references to this work will be to this edition and will be abbreviated $J F$. 
point for point to a Freudian case history of fetishism. In this regard, it throws into relief once again the close relationship between literary chronicles of perversion, pathology, criminal anomaly, and the genres of medical and criminological reportage. The criminologist Raymond de Ryckère, for example, began his study La Servante criminelle (1908) with a detailed textual explication of Mirbeau's Le Journal d'une femme de chambre. But the fact that literary and nonliterary case studies cross-reference each other during this period comes as no surprise. What constitutes a more interesting problem, it would seem, is the way in which servitude, erotic submission, and foot fetishism are curiously enmeshed within a complex system of representation centering on the maid. On one level the characterization of the maid signals problems of class structure within literary hierarchy itself-questions concerning textual agency, typology, and stereotype, boundaries holding between "master narratives" and "servant texts." On another level, the strangely suppressed power of the récit de la bonne allows for a revisionist reading of the role of the female domestic within Freudian theory; for, as we shall see, though the housemaid enters and exits frequently in Freud's case histories, her role within bourgeois neurosis is barely touched upon. One must look to Mirbeau's novel for a ramified "reading" of domestic fetishism, both in the sense of an interiorized, domesticated psychopathology, and in the sense of a servant-inspired erotic economy expressed through specific laws, codes, and semiobscured or scotomized iconographic insignia.

In Mirbeau's novel, Célestine muses on the signification of the word bottine ("Cela avait donc un sens?") and one might begin examining the role of the boot as a figure of fetishism by pursuing the direction of her speculation. Is the boot not a boot in the same way that Magritte's pipe is not a pipe? That is, a referential disavowal, a word, according to Foucault's assessment, that denounces its object as a false representation? ${ }^{2}$ Certainly insofar as the boot is the name of a fetish it possesses a doubly negative value, referring to what the maid is not: neither just an employee for domestic chores, nor the embodiment of desire, but something "split" between the two. Like Magritte's pipe, which might indeed turn into a boot if placed upside down such that its bowl becomes a heel and its stem the container for the sole of the foot, the boot is 1975).

2. Michel Foucault, Ceci n'est pas une pipe (Saint-Clément-la-Rivière: Fata Morgana, 
not a boot, but a visual bait, an object of voyeuristic fancy whose symbolic value depends entirely on the viewer.

In this respect, what is important in Mirbeau's account is not so much the maid, her name, or her boot but simply the "strangely dazzled look" of the master, for foot fetishism, as Freud defined it, involves a certain posture, glossed by Derrida as an "orientation," or "situation orientée, la syntaxe d'un mouvement vers le haut, depuis le très-bas, le plus-bas [oriented situation, the syntax of a movement toward the top, from the very bottom, the lowest]."3 In his 1927 essay "Fetishism," Freud elucidated the crucial role of this attitude in the subject's choice of a fetish object:

One would expect that the organs or objects selected as substitutes for the penis whose presence is missed in the woman would be such as act as symbols for the penis in other respects. This may happen occasionally, but it is certainly not the determining factor. It seems rather that when the fetish comes to life, so to speak, some process has been suddenly interrupted-it reminds one of the abrupt halt made by memory in traumatic amnesias. In the case of the fetish, too, interest is held up at a certain point-what is possibly the last impression received before the uncanny traumatic one is preserved as a fetish, or part of it, to the circumstance that the inquisitive boy used to peer up the woman's legs towards her genitals. ${ }^{4}$

According to Freud, the shoe becomes a potential fetish not so much because it imitates the form of the absent phallus but rather because it emerges as an indexical (pointing upward) or metonymical object placed in the line of vision of the curious boy whose gaze travels from below ("le très-bas, le plus-bas") to above. This approach from the base may be interpreted alternatively as part of a larger vertical structure of idealization and idolatry typifying the fetishist's attitude to his maternal phantasm, or as an active form of debasement when read as a virtual synonym of the master's approach to the family chambermaid. Conventionally, he attacks from behind, furtively lifting her skirts as she bends over to dust or straighten a household object. This bestial posture, in addition to providing a perfect paradigm of class exploitation, also implies a mock or counter version of the gentlemanly pastime of the hunt,

3. Jacques Derrida, La Vérité en peinture (Paris: Flammarion, 1978), p. 305. See "Restitutions" for Derrida's reading of foot fetishism.

4. Sigmund Freud, "Fetishism" (1927), in Standard Edition 21:149. 
with its sado-erotic paraphernalia of riding crops, laced-up saddles, bridles, spurs, and high boots.

The answer to Célestine's question "what does the boot signify?" is thus partially answered in her own name ("celestial," that which tends toward the ideal) and partially by the bias of Monsieur Rabour's axial and anatomically disjunctive vision-qualified by Freud as upward and occlusive, and by Jean Bellemin-Noël, elaborating on Freud, as "asymptotic," following the parallel lines of the legs disappearing into the shoes: ${ }^{5}$

- Il s'agenouilla, baisa mes bottines, les pétrit de ses doigts fébriles et caresseurs, les délaça....Et, en les baisant, les pétrissant, les caressant, il disait d'une voix suppliante, d'une voix d'enfant qui pleure: - $\mathrm{Oh}$ ! Marie... Marie ... tes petites bottines... donne-les-moi tout de suite.

- He fell to bended knee, and kissed my boots, kneading them with his feverish, fondling fingers, unlacing them.... And, while kissing, kneading, and fondling them, he said in a cajoling voice, the voice of a whimpering child: "Oh! Marie, Marie, your little booties-give them to me right now." (JF 39)

Like the maternal breast the boots are supplicated with childish promises of gifts and caresses; and, as if to complete this preFreudian mise-en-scène of a Freudian case history, the verb battre, "to beat," is used by the narrator to describe the flickering, upward gaze of Monsieur Rabour, as if betraying an inner phantasm of flagellation: "Monsieur s'emballait encore. A mesure qu'il parlait, ses paupières battaient, battaient comme des feuilles sous l'orage

5. Jean Bellemin-Noël, Gradiva au pied de la lettre (Paris: PUF, 1983), pp. 108-109. The name of the boot is also suggestive in terms of its own range of etymological significations. Bottine, the diminutive form of botte, has as its root a condition of podalic deformity, or clubfoot (bot), also active in the peasant's sabot, which, since the Middle Ages has connoted a vulgar, ungainly worker's shoe. The conjunction between lameness and the social underclass, with the associations ranging from one-leggedness (boiteux), signaling beggars or pilgrims on crutches, to the wooden leg (jambe de bois), described by Krafft-Ebing as a standard prop of the bordello, is only reinforced by the innuendos surrounding a secondary meaning. As tube, barrel, or drainpipe (cf. Littré, "tuyaux des lieux d'aisance"), the bot projects images of fecal evacuation and the maid's habitual corvée of emptying the chamber pot. This in turn is compatible with the stereotype of servants in the popular imagination as either born from or destined to "a life of the gutter." Linked through its Anglo-Saxon derivation to booty, meaning purse or money (bourse), the botte also evokes the theme of avarice, specifically that of the bourgeois master perennially bent on obtaining maximum labor for minimum cost. Finally, in vulgar parlance, it refers to the scrotum. In this context, the trivial expression "I would not want to be in your shoes" ironically projects the deeper nuances of castration anxiety. 
[Monsieur got excited again. As he spoke, his eyelids were batting, batting like leaves in a storm]" ( $J F 39$ ).

The quest for humiliation, part of the complex, inverted nature of fetishistic pleasure, is encapsulated by Mirbeau in the master's desire to polish the boots of the maid ("And it's I who will polish your booties, your little booties, your darling little booties..." $[J F$ 39]. As the agent of role reversal, with master becoming slave, the boot draws its value from classic depictions of the bootblack, head bent and body lowered in the posture of servitude, busying himself, as in Louis Aragon's arresting vignette in Le Paysan de Paris, with "putting suns" on shoes that are as dark as his profession. ${ }^{6}$ Monsieur Rabour's "strangely dazzling look" accordingly invites conjugation with that brilliant shine referred to by Freud as an attribute of the fetish. In the 1927 essay, he begins with the famous "Glanz auf der Nase," with the English pun on glance on the one hand evoking the primitive associations of the patient's mother tongue (English rather than German)-proof yet again of infantile fixation and the centrality of the sighting instinct-and on the other hand pointing to the disguise of shininess (as in the German Schein, or false appearance), used by the fetishist to divert attention from the essentially anal-erotic nature of his perversion. ${ }^{7}$ As Krafft-Ebing reported in his Psychopathia Sexualis, a certain aristocrat, seduced in childhood by a French governess who had aroused him with her boot, confessed attraction only to the elegant boots of his social station, the first and archetypal artifact being characterized by the glossy sheen of its black leather. ${ }^{8}$ Karl Abraham, in a case study that both drew from and greatly edified Freud, entitled "Remarks on the Psycho-Analysis of a Case of Foot and Corset Fetishism" (1910), also treated as significant his patient's avowed excitation when presented with patent-leather high-heeled shoes of the kind worn by prostitutes. ${ }^{9}$ And Janine Chasseguet-Smirgel, in her obser-

6. Louis Aragon, Le Paysan de Paris (Paris: Gallimard, 1978): "C'est le cireur, cela ne coûte que douze sous et nous sortirons de là avec des soleils au pied" (p. 86). ["It is the shoeshine parlour; let us make a brief halt there, it will cost us a mere sixty centimes, and we shall leave the place wearing suns on our feet": Paris Peasant, trans. Simon Watson Taylor (London: Picador, 1980), p. 82.]

7. Freud, "Fetishism," p. 150.

8. Richard von Krafft-Ebing, Psychopathia Sexualis, trans. Harry E. Wedeck (New York: Putnam's, 1965), pp. 228-29.

9. Karl Abraham, "Remarks on the Psycho-Analysis of a Case of Foot and Corset Fetishism" (1910), in Selected Papers of Karl Abraham, trans. Douglas Bryan and Alix Strachey (New York: Basic Books, 1953), p. 126. 
vations of the frequency with which waxed surfaces, satin undergarments, and gleaming boots are coupled with malodorous sense impressions, concludes that the fetish has an essentially double nature: grotesque and excremental, ideal and pristine. ${ }^{10}$

This brings us to what is perhaps the most salient link between the boot and the maid-the common association with dirt. In a famous note added in 1915 to Three Essays on the Theory of Sexuality Freud provided an explanation for this association in his discussion of the coprophilic origins of foot fetishism: "Both the feet and the hair are objects with a strong smell which have been exalted into fetishes after the olfactory sensation has become unpleasurable and been abandoned. Accordingly, in the perversion that corresponds to foot-fetishism, it is only the dirty and evil-smelling feet that become sexual objects." "11 Reverting to a stage of development prior to the repression of his scatological instincts, Monsieur Rabour plays the part of boot-licker, pandering to his desire to taste his own dirt accumulated on her boots. At the closure of Mirbeau's set piece, he lies dead, the boot, fittingly enough, having choked him to death:

- Monsieur était mort!...Etendu sur le dos, au milieu du lit, le corps presque entièrement nu, on sentait déjà en lui et sur lui la rigidité du cadavre.... Spectacle terrifiant qui, plus encore que ce visage, me secoua d'épouvante... Monsieur tenait, serrait dans ses dents, une de mes bottines, si durement serrée dans ses dents, qu'après d'inutiles et horribles efforts je fus obligée d'en couper le cuir, avec un rasoir pour la leur arracher.

- Monsieur was dead! Stretched out on his back, in the middle of the bed, his body almost entirely naked, one could already feel on him the rigidity of the corpse.... And then, a terrif ying spectacle, one which, even more than his face, sent shock waves of horror through me... Monsieur held, clenched between his teeth, one of my boots, so firmly clenched between his teeth, that after much useless and horrible effort, I was forced to cut through the leather with a razor in order to tear out the boot. $\left(J F 4^{0}\right)$

In addition to affording a virtual textbook illustration of fetishism

10. Janine Chasseguet-Smirgel, Ethique et esthétique de la perversion (Seyssel: Champ Vallon, 1984), pp. $285^{-89}$.

11. Freud, Three Essays on the Theory of Sexuality, in Standard Edition 7:155. 
as coprophilia, this macabre tableau can be read as a castration drama in reverse: the boot, a displaced female phallus whose absence excites Monsieur Rabour's castration anxiety, symbolically returns (albeit in the wrong place), conjuring up Roland Barthes's conception of a text as a fetish object that desires him ("Le texte est un objet fétiche et ce fétiche me désire"). ${ }^{12}$ A materialized lack, a fetish that "bites back," the boot becomes the agent by which the female phallus is symbolically reappropriated by its original owner, as Célestine, after overcoming her disgust, proceeds pragmatically to cut out the boot with a razor.

The motifs of mutilation, violation, and corporal dismemberment must certainly be added to the list of fetishistic topoi foreshadowed in the novel by this central episode. But what makes the episode more than just a miniature, concentrated version of the entire novel, and more than just a literary rendering of a pathological case history that influenced the psychiatric community in the early twentieth century, is its value as a theory of the particular relation of fetishism to the representation of the female domestic. Charcot, Binet, Krafft-Ebing, and Freud all record examples in which a maid or governess appears. All systematically neglect, however, to explore the relevance of the maid qua maid in her position as either maternal surrogate or medium of power transfer from servitude to domination in their study of specific perversions. In his essay "The Role of Fetishism in Love," Binet refers to boot nails, aprons, nightcaps, underlinen, and the white headband traditionally worn by the French maid as a class of objects provocative to fetishists but fails to discern in this vestimentary code the classic costume of the maid. ${ }^{13}$ Although in one case history he notes the presence of an old servant, he passes over the detail with no comment: "The nightcap lover recounts that at the age of five he slept in the same bed as one of his parents, and that when the parent donned a nightcap, he would get a continual erection. Around the same time, he saw an old servant get undressed, and when she put her nightcap on, he would get very excited and again become erect." 14

Freud drew on this very passage in tracing the etiology of fetishism to fixations of early childhood, differing with Binet only in his belief that the complex could be formed prior to the age of

12. Roland Barthes, Le Plaisir du texte (Paris: Seuil, 1973), p. 45.

13. Alfred Binet, "Le Fétichisme dans l'amour," Revue Philosophique 24(1887): 163.

14. Ibid., p. 166. 
five. ${ }^{15}$ Yet he too ignored the possible importance of the old servant, just as he did the governess in an unpublished paper entitled "A Case of Foot Fetishism," read before the Vienna Psychoanalytic Society in $1914 .{ }^{16}$ This case, according to Ernest Jones, "concerned a man of forty-five who had always been impotent," a condition presumably caused by "premature excitation of (the foot) by a very abnormal mother who used to caress and kiss it to excess." 17 Threatened by his father with castration, the boy became obsessed with the specter of the absent phallus:

- As a child he would lie with his head between his sister's thighs, and the sight of the female genital organ increased his fear of castration. When he was married he would dream that his wife was equipped with male organs. The sister in question had deformed legs from rickets, and it was her small foot that constituted his first ideal of a lovely, attractive organ-the foot. The perversion was evidently fixed by his seventh year, when he fell in love with his governess's foot. By then it had acquired the symbolic meaning of a male genital organ. ${ }^{18}$

Though the rickets and deformity of the foot (recalling the boot's etymological derivation from clubfoot) merit inclusion in the repertory of factors deemed significant in the case, the role of the governess as object of transference from the sister is not among them.

A similar obliviousness marked Freud's exhaustive analysis of Jensen's Gradiva in "Delusion and Dream in Jensen's Gradiva" (1907). While endeavoring to verify the plausibility of the antique Gradiva's step- "the left foot had advanced, and the right, about to follow, touched the ground only lightly with the tips of the toes while the sole and heel were raised almost vertically"-Norbert Hannold is hindered in his research by the long-skirted fashion of the upper-middle classes, "for almost no one but housemaids wore short skirts and they, with the exception of a few, because of their heavy shoes, could not well be considered in solving the problem." ${ }^{19}$

15. Freud, "Delusions and Dreams in Jensen's Gradiva," Standard Edition 9:47.

16. The Vienna Society had taken up the question of fetishism a number of times before, most notably in 1909. See above, note 23, Chapter 4 .

17. Ernest Jones, The Life and Work of Sigmund Freud, vol. 2, I901-1919 (New

York: Basic Books, 1955), p. 306.

18. Ibid.

19. Freud, "Delusions and Dreams," pp. 46-5o. For an interesting reading of the Gradiva's foot, see Alain Roger, Hérésies du désir: Freud, Dracula, Dali (Seyssel: Champ 
The boots of the servant class could thus in no way be adduced as evidence for a girl "splendid in walking." Freud, while recognizing Hannold's "fetishistic erotomania" (prompting him to venerate the Gradiva as an idealized statue on a pedestal and to endue her with an exalted genealogy as the daughter of a patrician "associated with the temple service of a deity"), also avoids investigating the particular connections between the lower-class maid's boot and the upperclass lady's foot. ${ }^{20}$

Freud ignored the maid again in his analysis of the "French Nurse's Dream" taken from a Hungarian comic strip discovered by Sandor Ferenczi that bore this caption and added to The Interpretation of Dreams (1899) in 1914. The cartoon features a child in the company of his nurse urinating prodigiously against a wall like Gargantua on the city of Paris: "The stream of water produced by the micturating boy becomes mightier and mightier. In the fourth picture it is already large enough to float a rowing boat; there follow a gondola, a sailing ship and finally a liner." ${ }^{21}$ The final frame shows the nurse awaking and attending to the distressed child-his urgent need to relieve himself having apparently been transposed into her wet-dream. Freud passed over the symbolism of the nurse as object of infantile anal-eroticism, despite the fact that his own dreams contained imbricated analogies between feet and bedwetting (in the "Dream of Count Thun" the Count translates the German flower "cat's foot" as pisse-en-lit); between maids and "dirty feet"; and between maids, nurses, and childhood exhibitionism. These analogies come most sharply into focus in one of the staircase dreams (and here one must not forget the transition from gradus (step) to "Gradiva"), a dream in which Freud, in a state of undress, experiences painful embarrassment upon encountering a maid on the staircase: "I was glued to the steps and unable to budge from the spot." 22 Analyzing his sense of shame he remained perplexed by the fact that it was an "older... surly and far from attractive" maidservant who had prompted such feelings. Further reflection reminded him of his ongoing warfare with a concierge over the installation of a spittoon on the stair of a house where he

\footnotetext{
Vallon, 1985).

20. Freud, "Delusions and Dreams," pp. $5^{0-51}$.

21. Freud, The Interpretation of Dreams (1899), Standard Edition, 4-5:367.

22. Ibid., p. 238.
} 
frequently visited a patient. Freud would expectorate on the staircase in protest of the absence of a receptacle, and the concierge, lying in wait, would berate him for his impropriety. Here, in the paradigm of dirt versus cleanliness, Freud found the clue to the maidservant, for she had appeared in a prior dream complaining: "You might have wiped your boots, doctor, before you came into the room today. You've made the red carpet all dirty again with your feet." ${ }^{23}$ Noting the structural affinity between these points of the dream and the legend, read as a child, of Odysseus "when he appeared, naked and covered with mud, before the eyes of Nausicaä and her maidens," Freud, delving still deeper, recalled the memory of his own nurse:

- According to what I was told not long ago by my mother, she was old and ugly, but very sharp and efficient. From what I can infer from my own dreams her treatment of me was not always excessive in its amiability and her words could be harsh if I failed to reach the required standard of cleanliness. And thus the maid-servant, since she had undertaken the job of carrying out this educational work, acquired the right to be treated in my dream as a reincarnation of the prehistoric old nurse. It is reasonable to suppose that the child loved the old woman who taught him these lessons, in spite of her rough treatment of him. ${ }^{24}$

The significance of this "prehistoric old nurse," object of conflicted affection, has been until recently curiously underestimated in terms of its psychoanalytic import. Freud evinced a consistent distrust toward feminine domestics, even when analyzing the banal accidents committed by servants while cleaning up:

- When servants drop fragile articles and so destroy them, our first thought is certainly not of a psychological explanation, yet it is not unlikely that here, too, obscure motives play their part. Nothing is more foreign to uneducated people than an appreciation of art and works of art. Our servants are dominated by a mute hostility towards the manifestations of art, especially when the objects (whose value they do not understand) become a source of work for them. ${ }^{25}$

While Freud cites this type of casual destruction allusively, that is, in conjunction with the Jewish marriage ritual of breaking the vessels,

23. Ibid., p. 239 .

24. Ibid., p. $247-48$.

25. Freud, The Psychopathology of Everyday Life (1901), Standard Edition 6:1 73 . 
and while he recognizes its everyday symbolic import as an act of displaced class conflict, he submerges what would seem to be an obvious connotation: the sexual initiation or "breaking in" customarily performed by the maid on the young master. The reason for his suppression of this social cliché may perhaps lie in the matrix of partial avowals and disavowals surrounding the role of his own nursemaid during his early sexual education. In the course of his self-analysis in 1897 he confided to Fliess that his Urheberin (translated as "primary originator" or, more literally, "the first woman to raise up") "was my teacher in sexual matters and complained because I was clumsy and unable to do anything."26 Though the implications of this confession for the oedipal theory have been explored in Jim Swan's "Mater and Nannie: Freud's Two Mothers and the Discovery of the Oedipus Complex," though its relevance to the controversy surrounding the literalness of Freud's abandoned "seduction theory" has been acknowledged (cf. Masson and McGrath), and though its analogous structure to the relationship between analyst and (female) analysand has been elucidated, it is primarily in Freud's analysis of a case not his own, but strangely parallel, that the full significance of such a screen memory is adumbrated. ${ }^{27}$

In his presentation of the case of the Wolf-man, narrative suspense accrues around the question of who induced the Wolf-man's fear of castration. First it appears to be an English governess, alcoholic and sadistic, who, gathering up her skirts behind her, cried, "Do look at my little tail!" But despite her threatening behavior, the real object of fantasy is identified as the Wolf-man's sexually precocious sister. The servant is nonetheless reinscribed in the initial paradigm of displacement when we learn that the sister's sexual rebuff prompts the Wolf-man to choose as surrogate a housemaid bearing the first name of his sibling. Freud attached considerable importance to this love choice, observing that "all the

26. The Complete Letters of Sigmund Freud to Wilhelm Fliess ( $1887-1904)$, trans. and ed. Jeff rey Moussaieff Masson (Cambridge: Harvard University Press, 1985), p. 268.

27. A small bibliography on the role of the nursemaid or governess in Freud's work includes Jim Swan, "Mater and Nannie: Freud's Two Mothers and the Discovery of the Oedipus Complex," American Imago 31 (Spring 1974): 1-64; Kenneth Grigg, "All Roads Lead to Rome: The Role of the Nursemaid in Freud's Dreams," Journal of the American Psychoanalytical Association 21 (1973): 108-26; Jane Gallop, "Keys to Dora," in In Dora's Case: Freud-Hysteria-Feminism, ed. Charles Bernheimer and Claire Kahane (New York: Columbia University Press, 1985), pp. 214-16; William J. McGrath, Freud's Discovery of Psychoanalysis: The Politics of Hysteria (Ithaca: Cornell University Press, 1986); and Nicolas Abraham and Maria Torok, Cryptomanie: Le Verbier de l'Homme aux Loups (Paris: Aubier Flammarion, 1976). 
girls with whom he subsequently fell in love-often with the clearest indications of compulsion-were also servants, whose education and intelligence were necessarily far inferior to his own." ${ }^{28}$ As the story progresses, suspicion falls on the Wolf-man's "Nanya," who, according to Freud, evinced an "untiring affection" for her charge, treating him as a "substitute for a son of her own who had died young." His attempts to seduce "Nanya" by masturbating in her presence provoke her warning against an eventual "wound in the place." Yet, Nanya's comment, like that of the English governess, diminishes in importance next to the images associated with Grusha, a third housemaid, retrieved at an advanced stage of the analysis. Grusha is the prototype of the wolf. Her animal posture, "on the floor engaged in scrubbing it... kneeling down, with her buttocks projecting and her back horizontal," perfectly matches the posture of the boy's mother, viewed a tergo in a primal scene. ${ }^{29}$ To "debase" (Freud's term) Grusha, and then later "Matrona" (another family servant whose maternal name Freud does not fail to note), is thus revealed as part of a traceable urge to debase or punish both mother and intellectually superior sister. But immediately as Grusha emerges as the agent of transference from the sister or mother to a surrogate object of anal eroticism, Freud, treating her like a servant, relegates her once more to the status of vehicle, useful for clarifying the analysis but no longer an integral part of the Wolfman's psychic history: "It was true that there could be no doubt about the scene with Grusha, but, I suggested, in itself that scene meant nothing; it had been emphasized ex post facto by a regression from the circumstances of his object-choice, which, as a result of his intention to debase, had been diverted from his sister on to servant girls."30

The contemptuous claim that Grusha's scene "meant nothing" brings us back to an earlier moment in Freud's career to a draft of "The Architecture of Hysteria," enclosed in 1897 in a letter to Fliess. Here we find under the heading "The Part Played by Servant Girls" a statement of the housemaid's pure instrumentality in Freud's mind; her position as a kind of psychoanalytical "hired help" or "second hand," subordinate to a "master" pathology:

28. Muriel Gardiner, The Wolf-man by the Wolf-man (New York: Basic Books, 1971), p. 167.

29. Ibid., p. 234.

3o. Ibid., p. 236. 
- An immense load of guilt, with self-reproaches (for theft, abortion), is made possible by identification with these people of low morals who are so often remembered, in a sexual connection with father or brother, as worthless female material. And, as a result of the sublimation of these girls in fantasies, most improbable charges against other people are contained in the fantasies... There is a tragic justice in the circumstance that the family head's stooping to a maidservant is atoned for by his daughter's self-abasement. ${ }^{31}$

The complex imbrication of fear, disdain, and culpability that surfaces in this passage helps to explain Freud's consistent suppression of the maid once she appeared in her unmasked state as maternal castrator. This suppression has been remarked upon by a number of critics from Peter Stallybrass and Allon White (The Politics and Poetics of Transgression) to Hélène Cixous and Catherine Clément. ${ }^{32}$ The latter two, in The Newly Born Woman, excoriate Freud for his exclusion of the maid. "She is the hole in the social cell," Cixous remarks; “'It' goes through 'that,' it goes through her body. In 'Dora' what was terrifying was that these archetypal servants were put by Freud himself in 'the maid's room'-that is, in the notes." ${ }^{33}$ While Cixous and Clément are here concerned to oppose a "mistress" language to the discourse of mastery, they themselves stumble over the maid, whose "station," beneath the mistress, proves difficult to dislodge. Ultimately, they too are implicated as intellectual mistresses when they shift the burden of class insensitivity onto Freud. "Freud in relation to Dora was in the maid's place," claims Cixous, referring to the fact that he was fired by Dora, just as a servant girl is fired by her mistress. ${ }^{34}$ If Freud is a maid, if the analyst is seen as subordinate to the analysand rather than the reverse in this heretical feminist scheme, a class injustice is certainly redressed. But by focusing on Freud, we once again elide the imago of the maid. An objective correlative of the return of the repressed, a living embodiment of the commodity fetish (and here it must be recalled that the "possession" of servants functioned as a mark of

31. Letters of Freud to Fliess, p. 241.

32. For an analysis of the maid that closely parallels my own (and which came to my attention after I had written this chapter), see Peter Stallybrass and Allon White's section entitled "Below Stairs: The Maid and the Family Romance," in The Politics and Poetics of Transgression (Ithaca: Cornell University Press, 1986), pp. 149-70.

33. Hélène Cixous and Catherine Clément, The Newly Born Woman, trans. Betsy Wing (Minneapolis: University of Minnesota Press, 1986), p. 150.

34. Ibid., p. $15^{2}$. 
prestige and wealth, as much decorative as functional), the maid seems doomed to displacement and emargination.

Though Cixous, Clément, Gallop, and Stallybrass and White have done much to counter the tendency within psychoanalytical (master) narratives to ignore issues of class and gender, one might go even further in this direction. The maid as quintessential fetish object, both instigator of, and antidote to, castration anxiety, merits consideration as a significant theoretical agent within a more historicized understanding of psychoanalysis. Representing the maid, however, proves to be no simple task. Her portrait may be constituted from the outlines of her absence in the master narratives, or, alternatively, from a neglected genre of servants' tales in nineteenthand twentieth-century literature: Lamartine's Geneviève (1850), the feuilleton Bécassine, Zulma Carraud's Une Servante d'autrefois (1866), and Paul Bourget's Une fille-mère (1928), as well as the more familiar works by Zola, the Goncourts, Flaubert, Maupassant, Proust, and Genet.

In the late-nineteenth-century culture in which Freud's theories took root, the body of the maid became increasingly present in the phantasms, paranoias, and phobias of the middle class. As a result of its direct physical contact with the secret detritus of the bourgeois household, the maid's body became symbolically contaminated by the taches, or traces of dirt, that it was her tâche, task or work, to efface. A magnet for microbes-the newly discovered agent of infection that every decent bourgeois fought to expunge-the maid was to be eschewed, alienated like a carrier of smallpox or syphilis, which she was also presumed to attract through a wanton life-style of promiscuity and nomadism. ${ }^{35}$ These associations were most powerfully captured by Zola in Pot-Bouille (1882), where the scullery maid, Adèle, lowest in the servant hierarchy, is referred to continuously as a creature of filth, a "slattern" (souillon), a "rag" (torchon), "a dirty, ungainly beast on whom the whole household beat up ["une bête sale et gauche sur laquelle la maison entière tapait]." ${ }^{36}$ Avoided by all except the master and his son, who take turns with her in her bed (the father, Duveyrier, having been banished from his wife's

35. See chap. 3, "Le Camouflage de la maladie," in Isabelle Grellet and Caroline Kruse, Histoires de la tuberculose: Les Fièures de l'âme, I 80o-1940 (Paris: Ramsay, 1983), for discussion of how the new organization of the bourgeois house introduced the radical separation of the maid's quarters. For an account of the links between domestic service and prostitution, see Anne Martin-Fugier's La Place des bonnes: La Domesticité féminine à Paris en 1900 (Paris: Grasset, 1979), pp. 317-31.

36. Emile Zola, Pot-Bouille (Paris: Gallimard, 1982), p. 136. 
boudoir because of the repugnant "bleeding spots on his forehead"), Adèle becomes the repository of these very taches, of all that is deemed untouchable by the rest of the household. ${ }^{37}$ The cruel nickname "rag" perfectly conveys her dehumanized status as that which "wipes away" the "hidden family dirt [les ordures cachées des familles]" lurking in the pestiferous courtyards and kitchens of the bourgeois residence. ${ }^{38}$

In Madame Bovary, the coordinates of this typology had already been set. At the peak of Emma's affair with Rodolphe, her maid, Félicité, is charged with cleaning off her adulterous taint: "Il fallait que la domestique fût sans cesse à blanchir du linge [The maid was constantly at work cleaning her linen]." Eventually the roles of servant and mistress are ironically confused as when Emma, submitting to her lover, describes herself as a maid: "Je suis ta servante et ta concubine! [I am your servant and your concubine!]." ${ }^{39}$ If here Emma evokes enslavement and subordination with romantic idealism, suggesting a suppressed longing to recover the fatal spot that she has passed off onto her servant, the reverse occurs within the monologues of Genet's Claire. While playing the role of "Madame," she histrionically reviles the scum of servitude:

Je hais les domestiques. J'en hais l'espèce odieuse et vile. Les domestiques n'appartiennent pas à l'humanité. Ils coulent. Ils sont une exhalaison qui traîne dans nos chambres, dans nos corridors, qui nous pénètre, nous entre par la bouche, qui nous corrompt. Moi je vous vomis.... Vos gueules d'épouvante et de remords, vos coudes plissés, vos corsages démodés, vos corps pour porter nos défroqués. Vous êtes nos miroirs déformants, notre soupape, notre honte, notre lie.

- I loathe servants. A vile and odious breed, I loathe them. They're not of the human race. Servants ooze. They're a foul effluvium drifting through our rooms and hallways, seeping into us, entering our mouths, corrupting us. I vomit you! ... Your frightened guilty faces, your puckered elbows, your outmoded clothes, your wasted bodies, only fit for our castoffs! You're our distorting mirrors, our loathsome vent, our shame, our dregs! $!^{40}$

37. Ibid., p. 162 .

38. Ibid., p. 137 .

39. Gustave Flaubert, Madame Bovary (Paris: Garnier Flammarion, 1966), pp. 216 , 219.

40. Jean Genet, Les Bonnes, as cited by Martin-Fugier, La Place des bonnes, p. 193; Genet, The Maids, trans. Bernard Frechtman (New York: Grove Press, 1962), p. 86. 
In this self-hating impersonation there lies a full spectrum of thematic variations on the maid's tache: a ubiquitous odor that trails through the house, invisible yet felt as a discomfiting presence; a disease that trickles down from the cramped, unhealthy quarters of the sixth floor; a sign of the social pariah who survives, like carrion, on human waste; a clown, outfitted in the rags and castoffs of its noble superior, and as such, the grotesque double of the class it serves.

Each of these motifs is extensively treated as part of the historical biography of a maid's life recorded in Le Journal d'une femme de chambre. In an act of absolute devotion to a young, sickly master, Célestine yields to a dangerous embrace. Her charge, afflicted by tuberculosis, has lost all interest in life until the day when she initiates him in love. From then on, their passion grows proportionally with the boy's expenditure of force until, a mere skeleton, he dies in her arms in a paroxysm of desire. Before he expires, however, Célestine affirms her willingness to render the supreme "service":

- Mon baiser avait quelque chose de sinistre et de follement criminel... Sachant que je tuais Georges, je m'acharnais à me tuer, moi aussi, dans le même bonheur et dans le même mal.... Délibérément, je sacrifiais sa vie et la mienne.... Avec une exaltation âpre et farouche qui décuplait l'intensité de nos spasmes, j'aspirais, je buvais la mort, toute la mort, à sa bouche ... et je me barbouillais les lèvres de son poison.... Une fois qu'il toussait, pris, dans mes bras, d'une crise plus violente que de coutume, je vis mousser à ses lèvres un gros, immonde crachat sanguinolent.

-Donne...donne...donne!

Et j'avalai le crachat, avec une avidité meurtrière, comme j'eusse fait d'un cordial de vie.

- My kiss had something sinister and madly criminal in it. Knowing that I was killing Georges, I threw myself into killing myself, myself also, with the same pleasure and the same pain.... Deliberately I sacrificed his life and mine... With a bitter, wild exultation that increased the intensity of our spasms tenfold, I drank, I inhaled death, all of death, from his mouth.... I sullied my mouth with his poison. At the point where he was coughing, seized, while in my arms, by a particularly violent fit, I saw a huge, bloody glob of spit foam over his lips.

"Give it to me!...Give it to me!...Give it to me!"

And I swallowed the spittle with murderous greed, as if it was a potion of life. $(J F$ 16o) 
Clearly a travesty of biblical parables of abasement, particularly that of Christ and the lepers reworked by Flaubert in La Légende de Saint-Julien l'hospitalier, this scene borders on the pornographic with its intimations of fellatio and incest (the latter if it is recalled that Célestine acts as a maternal surrogate to Georges). The aura of transgression is reinforced by the sacrificial communion where poison is imbibed with fervor. This ignominious crachat (sputum) brings us once again to that expectoration on the stairs, which, in a footnote, Freud admitted to "over-interpreting." The semantic slippage of spuken, meaning "haunting," toward its homonym spucken, or spitting on the stairs, yielded, according to Freud, the expression esprit d'escalier. ${ }^{41}$ Though Freud neglects to recognize the maid in this figure of the staircase genie (despite the sense of shame that overcomes him when they meet), she appears not so distant from Mirbeau's Célestine. Both are associated with defilement and abjection.

Though it may be tempting to read this scene simply as evidence of Mirbeau's misogynist contempt for the sexual appetites of women, all of whom in his eyes resemble his working-class heroine insofar as they are "slaves to passion" and even capable of "killing a man with their lust," it should also be approached as a pure parody of the stock low literature of the nineteenth century, featuring the maid as a servant of God. Heroic feats of selflessness constituted the standard trope of the genre, which was especially popular for obvious propagandistic reasons among the clergy, the bourgeois matron, and the directors of employment agencies for the placement of domestics. Typically, the servant risked her life for that of the master's children, as when, in Flaubert's Un Coeur simple (an example of the theme percolating up into high literature), Félicité braces a raging bull and survives only by throwing clumps of earth into its eyes. Similarly, in Lamartine's Geneviève (1850), the outer limits of self-abnegation are attained when, having sacrificed love, fortune, and honor for the sake of a perfidious sister, she is imprisoned, branded as a social outcast, and ultimately forced to submit to the final humiliation of serving the family of her former suitor, now married and prosperous. A "paschal lamb" whose unflagging resignation indeed approximates that of a "beast of burden" (held up as an ideal model of comportment for the servant throughout this literary genre), Geneviève is nonetheless equaled in trials by Fanchette Madoré in Zulma Carraud's Une

41. Freud, The Interpretation of Dreams, p. 281. 
Servante d'autrefois (1866). In this novel by a close friend of Balzac, one discovers what may have been the precedent for Mirbeau's description of the gob of spit in Fanchette's "cure" for smallpox, administered lovingly on the child of her mistress:

- Le médecin ayant dit qu'Elisabeth serait très défigurée si elle en réchappait, Fanchette se souvint d'avoir entendu dire à sa grande-mère qu'en perçant chaque bouton avec une aiguille fine, et qu'en ayant le courage d'en aspirer le contenu, la maladie ne laissait aucune trace. La brave fille se mit à l'oeuvre aussitôt qu'elle se trouva seule avec l'enfant, et persévera sans la moindre répugnance jusqu'à ce que les boutons fussent desséchés.

- The doctor having said that Elisabeth would be very disfigured after her recuperation, Fanchette remembered hearing someone say to her grandmother that by piercing each pimple with a fine needle, and courageously sucking the contents, the illness would leave no trace. The plucky girl set to work as soon as she was alone with the child, persevering without any repugnance until all the spots were drained. ${ }^{42}$

As in Le Journal d'une femme de chambre, the transcendence of physical repulsion proves to be the test of true fidelity; but where Célestine is at least allowed a shred of egoism in her fear of contagion, Fanchette is permitted none. Moreover, unlike Célestine, she is cruelly remunerated for her supreme act of Christian virtue with the contraction of the disease:

- Mais la pauvre fille ressentit bientôt, elle aussi, les symptômes de la contagion. Elle fut très malade à son tour, et très affectueusement soignée par Mme. Sionnet et ses deux filles aînées. Moins heureuse que l'enfant, ella porta toute sa vie des marques qui la défigurèrent.

- But soon, she too, poor girl, contracted the contagion's symptoms. In due course, she became very ill and was very kindly attended to by Mme. Sionnet and her two daughters. But less fortunate than the child, she would wear the disfiguring scars for the rest of her life. ${ }^{43}$

Fanchette's disfigurations emerge paradoxically as the very figurations of her masochistic humility, a pathological humility that accuses the master as it constitutes, on another level entirely, a

42. Zulma Carraud, Une Servante d'autrefois (Paris: Hachette, 1884), p. 16.

43. Ibid., p. 17. 
variant of the "semiology of the spot" as posited by Barthes in his essay on the signs of medical discourse. "These spots," notes Barthes, referring to the marks of disease on the face of a sick man, "refer to nothing else but themselves; they therefore necessitate no further reading or extended interpretation." ${ }^{44}$ The same may be said of Fanchette's, as, only surface deep, they refuse the traditional transparency between external flaws and inner defects. But where for Barthes the physiognomy of sickness points indexically to nothing but sickness, Fanchette's blemishes represent a maudlin sentimentality, if not nostalgia, for the loyal, self-effacing servante d'autrefois.

Lamartine's maid, Carraud's maid, or Freud's maid, whether covered with spots or blanked out by scopic fixations on other images, remains "invisible," a figment of agency, an "invisible hand." One could argue that insofar as her text is an "enabling discourse" in the literal sense of that term, that is, a discourse that helps "empower" the master narrative, then her "genre," as servant's text, is as marginal as her topological representation. Certainly this definition of her status is supported by literary history. As Erich Auerbach has argued, the maid in her original incarnation played the role of confidante, a receptive ear to the monologue of the mistress, a voice capable of expressing the sexual, reproductive, and materialistic urges suppressed by the master, and a facilitator of dramatic action, much like the stage directions or exordia appended to the great plays of the classical theater. ${ }^{45}$ But earlier I suggested that the maid's discourse eventually destabilized

44. Roland Barthes, "Sémiologie et médecine" (1972), in L' Aventure sémiologique (Paris: Seuil, 1985), p. 281. See also Michel Schneider's concept of the lisible plaie for a psychoanalytical rather than a semiological interpretation of corporal scripture in Blessures de mémoire (Paris: Gallimard, 1980), pp. 264-65.

45. Erich Auerbach, Mimesis: The Representation of Reality in Western Literature, trans. Willard R. Trask (Princeton: Princeton University Press, 1973). In his discussion of Molière, Auerbach wrote: "He [Molière] did not avoid the farcical and the grotesque, yet with him too any real representation of the life of the popular classes, even in such a spirit of aristocratic contempt as Shakespeare's, is as completely out of the question as it is with Boileau. All his chambermaids and servingmen, his peasants and peasants' wives, even his merchants, lawyers, physicians, and apothecaries, are merely comic adjuncts; and it is only within the frame of an upper bourgeois or aristocratic household that servants-especially women-at times represent the voice of down-to-earth common sense. But their functions are always concerned with their masters' problems, never with those of their own lives. Not the slightest trace of politics, of social or economic criticism, or of an analysis of the political, social and economic bases of life is to be found" (p. $36_{5}$ ). 
that of the master, and if we follow Bruce Robbins's analyses of Victorian fiction, this too is borne out by literary history. ${ }^{46} \mathrm{~A}$. J. Munby's "secret life" reveals the perverse imagination of a literary lawyer obsessed with a maid-of-all-work who continued to call him "Massa" even after their illicit marriage.

Munby recounts an extraordinary dream during which he justifies his love for a servant to her scandalized employer. With its language of crawling and lifting, abasement and condescension, affective debit and credit, this dream narrative highlights all the ambiguities of hierarchy and control implicit in the relationship between master and servant. A kind of domestic colonialism, this relationship is fraught with tensions created by the close personal contact of class and gender differences.

- And as I was speaking she had softly withdrawn from my side, and crossed the room and gone behind her master's seat: and suddenly I saw her reappear from under the sofa, crouched upon her hands and knees. Her face was pressed against the floor, between her outstretched arms; she moved forwards towards me, crawling on all fours, prone along the ground, as if she would abase herself to the utmost. I knew what was in her heart: I trembled with indignation at myself for letting her lie so low, with love and intense delight at the loveliness of her humility. So she crept up to my feet, and flung her lips upon them, and would have licked my boot.

Oh divine condescension to me unworthy! Her humiliation is gloriousmy lordliness is tyrannical and base. I know it, and rejoice in her triumph over me. So I lift her up and embraced her; and said to him-who had sat amazed the while-"Now, do you think she loves me? do you think I owe her any love?"47

In the French complement to Munby, found in the counternarrative, or "anti-maid's discourse," set up by, among others, Zola, Maupassant, and Mirbeau as an antidote to the saccharine, orthodox model, the indeterminacy of the maid as signifying agent is clearly in evidence. Here the stereotype of the faithful servant qua female cipher is straightforwardly undermined. This change can be historically explained, at least in part, by the transformation of class structure during the nineteenth century. As an arriviste middle class began

46. Bruce Robbins, The Servant's Hand (New York: Columbia University Press, 1986).

47. Derek Hudson, Munby, Man of Two Worlds: The Life and Diaries of Arthur J. Munby, I828-1910 (London: John Murray, 1972), pp. 182-83. 
increasingly to hire servants as a way of driving a wedge between itself and the proletariat, the codes and unwritten laws governing service became more and more ambiguous. A new resentment, or perhaps an old hostility more willingly expressed, developed between employer and employee, surfacing in the various bourgeois antipathies that centered on maids. If the "servant of god" fable was no longer possible, neither was the idealized moral epic of a servant's life featuring the dangers to a girl's virtue posed by a lascivious master. Eighteenth-century classics such as Richardson's Pamela and Marivaux's La Vie de Marianne yielded to the cynical visions of the Goncourts and Maupassant, who described in lurid detail the violent scenes in which servant girls lost their virginity and the promiscuous ways to which years of sexual brutalization forced them to become accustomed.

Le Journal d'une femme de chambre differs substantially from these anterior models insofar as it generates its discourse of the maid in the first-person singular. Mirbeau grafted the upper-class form of the mémoire intime onto the lower-class speech patterns and world view of a dispossessed yet self-reliant working woman. By restoring a voice to a silenced part of the population, he succeeded, like few other writers, in releasing the repressed text of servant resentment and inner revolt. To appreciate fully Mirbeau's departure from the norm, we can compare one of Célestine's monologues with a romantic, sentimentalized definition of the faithful servant. Lamartine, with lyrical didacticism, had offered in Geneviève a résumé of the old attitudes and values believed to prevail between master and servant:

J'ai toujours contemplé avec un pieux respect et avec un sourire d'attendrissement ce qu'on appelait l'esclave ou l'aff ranchi dans l'antiquité, la nourrice en Grèce, ou dans le moyen âge le domestique, c'est-à-dire la partie vivante de la maison, domus en France, la famille en Italie et en Espagne, véritable nom de la domesticité, car le domestique n'est, au fond, que le complément, l'extension de cette chère et tendre unité de l'association humaine qu'on appelle la famille; c'est la famille moins le sang, c'est la famille d'adoption, c'est la famille viagère, temporaire, annuelle, la famille à gages si vous voulez; mais c'est la famille souvent aussi incorporée, aussi aimante, aussi désintéressée, aussi payée par un salaire de sentiments, aussi dévouée à la considération, à l'honneur, à l'intérêt, à la perpétuité de la maison, que la maison même; que dis-je? souvent bien plus. 
I have always contemplated, with pious respect and a tender smile, that which one has called the slave or freedman in antiquity, the nurse in Greece, or domestic during the Middle Ages-that is, the living part of the household, -domus in France, famille in Italy and Spain; the true name for domesticity, because the domestic, in essence, is nothing but the complement, the extension of this dear and tender unity of that human association which we call the family. It is the family minus the blood ties, it is the family by adoption. It is the rented family, the family for a fee if you like, but of ten enough it is an incorporated family, as loving and disinterested, as paid by a salary of sentiment, as devoted to the care, honor, perpetuation, and general good of the household as the household itself; what can I say? of ten even more so than the household itself. $^{48}$

What is interesting about this exegesis of the social and historical origins of servitude is not so much its obvious note of hypocrisy, evident in oxymorons such as "la famille moins le sang" and "un salaire de sentiments" but, rather, the fact that Lamartine uses this very rhetoric of difference as part of a myth of domestic identity ("l'extension de cette...tendre unité"). Just as Rousseau would transform the noble savage into the citizen, so Lamartine would transform the plebian into the noble servitor.

Lamartine's disquisition is refuted virtually point for point by Célestine's counterdiscourse, which accentuates the notions of detachment, marginality, displacement, and anomie so blithely suppressed by Lamartine:

- Un domestique, ce n'est pas un être normal, un être social....C'est quelqu'un de disparate, fabriqué de pièces et de morceaux qui ne peuvent s'ajuster l'un dans l'autre, se juxtaposer l'un à l'autre.... C'est quelque chose de pire: un monstrueux hybride humain.... Il n'est plus du peuple, d'où il sort; il n'est pas, non plus, de la bourgeoisie où il vit et où il tend.... Du peuple qu'il a renié, il a perdu le sang généreux et la force naïve.... De la bourgeoisie, il a gagné les vices honteux.... Lâme toute salie, il traverse cet honnête monde bourgeois et rien que d'avoir respiré l'odeur mortelle qui monte de ces putrides cloaques, il perd, à jamais, la sécurité de son esprit, et jusqu'à la forme même de son moi.

- The servant, he's not a normal or social being. He's something disparate, fabricated out of spare parts and pieces that can't be made to fit together. He's something even worse: a monstrous human hybrid.... He is no longer of the people from whence he came; nor is he of the

48. Alphonse de Lamartine, Geneviève: Histoire d'une Servante (1850) (Paris: Nelson, 1925), p. 84 . 
bourgeoisie where he lives and to which he is drawn.... He has lost the fullbloodedness and simple force of the people he denied....From the bourgeoisie, he has acquired shameful vices. His soul covered with filth, he travels through this great bourgeois world, and simply by breathing the deadly odors rising up from these putrid cesspools, he loses, forever, not only his peace of mind, but also the very shape of his being. $\left(J F_{17}{ }^{17}\right)$

The semiotic of the tache ("l'âme toute salie") reemerges, making of the employer's dirty linen an unclean inner lining attached to the domestic self. Congruent neither with herself nor with her superiors or inferiors, the maid is destabilized and dislocated, becoming an omnibus signifier not only of modern defamiliarization but also of that which is monstrous.

And it is specifically this half-concealed monstrous character that can be detected in such stories as Maupassant's "Rosalie Prudent" and "La Mère aux monstres," featuring the maid as denatured mother. Both stories revolve around the crime of infanticide. In the former, Rosalie, seduced by the nephew of her employers, smothers both of the resulting twins rather than choose between them, for she can afford to support only one. In the latter, a similarly victimized maid avails herself of the "corset de force," but instead of dying, her infant is born deformed, and in order to survive expulsion from the village, the mother becomes a "montreur de phénomènes," thereby living off, by showing (monstrare), the monster (monstrum) she herself has created. ${ }^{49}$

Published in 1886 , this singularly horrific tale seems to have its precedent in Barbey d'Aurevilly's Une Histoire sans nom (1882) (itself a kind of rewriting of Heinrich von Kleist's Marquise von $O$ insofar as it revolves around a miraculous pregnancy), in which the mortified mother tries to stifle her daughter's future progeny with the same sinister method: "Elle laçait elle-même le corset de Lasthénie, et elle ne craignait pas de le serrer trop fort et de lui faire mal.... 'Avez-vous donc si peur que je vous le tue?' reprenait Mme de Ferjol avec une sauvage amertume. [She herself laced up Lasthénie's corset, and she never shrank from tightening it so hard that it hurt her.... 'Are you so afraid that I'm going to kill it?' Mme de Ferjol rejoined with a savage rancor]." ${ }^{50}$ Mirbeau, no doubt following Barbey and Maupassant, also used the image of the corset to

49. Maupassant, "La Mère aux monstres," in Contes et Nouvelles (1974), 1:845.

50. Barbey d'Aurevilly, Une Histoire sans nom, in Oeuvres romanesques complètes (1882; Paris: Gallimard, 1966), p. 318 . 
dramatize infanticide. In one of the vignettes of Le Journal d'une femme de chambre, an out-of-work gardener and his pregnant wife are sworn to sterility by a redoubtable countess, herself the tender mother of several children. The poor, she insists, must not encumber the estate with their supplementary charge, and so saying, fixes her exigent gaze on the distended stomach of the guilty woman. Having agreed to her terms, which are themselves the real crime against nature, husband and wife depart:

- La pauvre femme marchait péniblement, tirait la jambe. Comme elle étouffait un peu, elle s'arrêta, posa son sac à terre et délaça son corset.

-Ouf!... fit-elle en aspirant de larges bouffées d'air....

Et son ventre, longtemps comprimé, se tendit, s'enfla, accusa la rondeur caractéristique, la tare de la maternité, le crime...

Le malheur vint. Quatre jours après, la femme eut une fausse couche-une fausse couche? —et mourut en d'affreuses douleurs d'une péritonite.

- The poor woman walked with a painful gait, dragging her leg. Since she had trouble breathing, she stopped, put down her bag and unlaced her corset.

"Whew!" she said, taking large gulps of air.

And her stomach, so long confined, relaxed, swelled, and betrayed that characteristic roundess, that taint of maternity, the crime.

Ill fortune came. Four days later, the woman had a miscarriage-a miscarriage? - and died in terrible pain of peritonitis. (JF 332-33)

Despite the evident culpability of society in general, the figure of the servant as potential murderess is nonetheless fed as a popular phantasm, perhaps thereby insinuating itself into the Freudian imaginary as a fetishistic projection of the castrated mother. Such a characterization is fully present even in socially uncritical maids' narratives, as when Geneviève laments, "Parentes sans parenté, familières sans famille, filles sans mères, mères sans enfants, coeurs qui se donnent sans être reçus: voilà le sort des servantes devant vous! [Parents without relatives, intimates without families, daughters without mothers, mothers without children, hearts which offer themselves without ever being received, that is the fate of the servants in your midst!]" and as in Paul Bourget's implausible novella Une Fille-mère (1928), in which an unwed mother works as a faithful servant for her son, guarding her identity until her death 
so that he may conserve his improved class status. ${ }^{51}$ Each of these texts confirms the bourgeois distrust of maids as a class of maternally castrated women. They also help to explain why the preferred instrument of infanticide-the corset-might have come to be a fetish, standing in for what was lost to the maid. A punishing phantasm of deadly striations and knots, itself linking fetishism to sadomasochism, the image of the corset (as Karl Abraham, commenting on a patient's fascination with tying up, would observe) places part of the psychic anatomy "in bondage."

In his investigation of how certain "degenerate" practices such as alcoholism or debauchery become "contagious" in large urban areas, the turn-of-the-century sociologist Gabriel de Tarde formulated a set of behavioral laws alleged to govern the interaction between social classes at various hierarchical stations. The influence of his Les Lois de l'imitation (1895) is felt throughout Le Journal d'une femme de chambre, which at one level can be read as a didactic illustration of its principles. ${ }^{52}$ The law of "inside and outside" posits a collaboration between innate and learned behavior that manifests itself in the servant's acquired obedience, as well as his conventionally sanctioned outlets for revolt (group gossip sessions directed against the employer). More pertinent is the law of imitation of superiors by inferiors, which reveals itself as the major motive for Célestine's collusion with her fellow servant, Joseph. Despite her conviction that he is the culprit in the rape and sadistic murder of a village girl, she allows herself to be seduced by his promise to make her the proprietress of a café, so strong is her desire to become a "mistress" in her own right.

The most sardonic exposure of the bourgeois gentilhomme phenomenon is directed against Paul Bourget, whose society novels epitomized for Mirbeau the worst kind of literary prostitution. In $L e$ Journal, Bourget is portrayed as having so snobbish a fixation on the classes above that he disallows any extension of his famous "psychology" to members of the lower classes $\left(\begin{array}{ll}F & 118\end{array}\right)$. Taking

51. Lamartine, Geneviève, p. 301; Paul Bourget, Une Fille-mère, in Les Oeuvres libres (Paris: Fayard, 1928), p. 7 .

52. Gabriel de Tarde, Les Lois de l'imitation (Geneva: Slatkine, 1979). Tarde's influence is most discernible in the theory of Emile Durkheim and Roger Callois (see Denis Hollier, Le Collège de Sociologie, 1937-1939 [Paris: Gallimard, 1979]). 
Tarde's theory of imitation to the letter-"It's a recognized fact that we model our characters on that of our masters"-Célestine retaliates by inverting the paradigm of slave copying master. If Bourget refuses to grant a soul to servants, then he will be baptized a "soul drainer" (videur d'âmes), and as such, himself a maid: "Monsieur Jean vidait les pots de chambre...M. Paul Bourget vidait les âmes [Monsieur Jean emptied chamber pots; M. Paul Bourget emptied souls]". And lest there be any lingering doubts over the analogy, she adds: "Entre l'office et le salon, il n'y a pas toute la distance de servitude que l'on croit! [Between downstairs and upstairs, there's not such a servile distance as you would think!]" (JF 368$)$.

Despite her indignation in the face of Bourget's indifference toward his inferiors, Célestine replicates the same attitude. Mimicking the commodity fetishism of her superiors, she creates an altar to kitsch in the bare, insalubrious maid's room to which she is assigned:

- Demain, je tâcherai de m'arranger un peu...Au-dessus de mon lit, je clouerai mon petit crucifix de cuivre doré, et je mettrai sur la cheminée ma bonne vierge de porcelaine peinte, avec mes petites boîtes, mes petits bibelots et les photographies de monsieur Jean, de façon à introduire dans ce galetas un rayon d'intimité et de joie.

- Tomorrow, I'll try to set myself up a little. Above the bed, I'll nail my little brass crucifix, and I'll put my nice painted porcelain virgin on the mantelpiece, with my little boxes, my little knickknacks and the photographs of Monsieur Jean, by way of introducing a ray of intimacy and joy into this garret. $\left(J F 5^{6}\right)$

Here, the laws of imitation induce an unsettling affinity between proletariat and bourgeois. The modest icons of Célestine's past life project the aura of household gods, just like the hideous bibelots surinvested by her employers, the Lanlaires. Mirbeau seems to insinuate that a universalizing psychology of fetishization overrides the ideological differences of even the most historically divided social castes.

If commodity fetishism is the enemy of class consciousness in Mirbeau's study of the domestic socius, so too are the servant's aspirations. As she ascends the social ladder, Célestine conveniently "forgets" her own past, extending the laws of imitation to the mistreatment of the domestics now beneath her. Established with 
Joseph in her Cherbourg bistro, she complains: "They're impossible, these maids of Cherbourg, promiscuous and thieving! No, it's simply incredible, disgusting" ( $J F 383$ ). Proust would also capture this sociological law in his portrait of Françoise, who, a loyal servante d'autrefois, exhibits no animosity when ordered to go upstairs for nothing (according to an idle whim of Tante Léonie) but displays unmitigated outrage at being told to go downstairs for something, such as the malady of a scullery maid:

- Une de ces nuits qui suivirent l'accouchement de la fille de cuisine, celle-ci fut prise d'atroces coliques: maman l'entendit se plaindre, se leva et réveilla Françoise qui, insensible, déclara que tous ces cris étaient une comédie, qu'elle voulait "faire la maîtresse."

- One night, shortly after her confinement, the kitchen-maid was seized with the most appalling pains; Mamma heard her groans, and rose and awakened Françoise, who, quite unmoved, declared that all the outcry was mere malingering, that the girl wanted to "play the mistress."53

Clearly "playing the mistress" herself as she accuses the scullery maid, Françoise, like Célestine, like Paul Bourget, demonstrates the law of imitation from below to above, thus giving a social ascription to the direction of the Freudian gaze.

Mirbeau, again following Tarde, also describes a process that might be called "reverse fetishism" whereby the master, imitating his subordinate, seems impelled downward by some magnetic force. Here, the interchangeability of idealization and humiliation, emphasized by Freud and Karl Abraham in their descriptions of the contradictory impulses of fetishism, becomes most apparent. Jealous of Célestine's good looks and openly avowed weakness for sexual adventure, one of her mistresses becomes a part-time streetwalker, returning from her escapades with her underwear torn and dirty, her corset and garters unlaced, and her hair covered with the feathers of a stranger's pillow. In another instance, a mother anxious to keep her son at home uses Célestine as sexual bait, manipulating her like a madam in a bordello. Lending herself to a game of mimetic rivalry whose object is the ignominious son, Célestine descends to the level of a prostitute, dragging her mistress down with her even further in the course of their altercations:

53. Marcel Proust, Du côté de chez Swann (Paris: Gallimard, 1954), p. 149. Marcel Proust, Remembrance of Things Past, vol. 1, trans. C. K. Scott Moncrieff and Terence Kilmartin (New York: Vintage, 1982), p. 133. 
"They descended to the vocabulary level of common hookers" ( $J F$ 258). A variation of this law of negative imitation can also be found in Germinie Lacerteux at the pivotal moment where servant and mistress exchange roles. Having attained "the lower depths," her depravity reigning in the filth and disorder of the household, Germinie terrorizes her lenient mistress, Mademoiselle de Varandeuil, to the point where the latter becomes the "servant of the servant": "Parfois, quand Germinie était sortie, elle se hasardait à donner avec ses mains goutteuses un coup de serviette sur la commode, un coup de plumeau sur un cadre. Elle se dépêchait, craignant d'être grondée, d'avoir une scène, si sa bonne rentrait et la voyait. [Occasionally, when Germinie was out, she risked, with her goutridden hands, giving a wipe to the commode, a shake of the featherduster to the picture frame. She hurried, fearing a scolding or a scene, if her maid were to return and see her]." ${ }^{54}$ The Goncourts imply an explanation for this reversal in the prehistory of Mlle de Varandeuil's life with Germinie. Faced with adversity during the Revolution, Mademoiselle had been forced by her father to serve both him and the real maid, with whom he has had a child. With this dreadful past behind her, the act of serving Germinie is comparable to the resurgence of an atavism, as if to confirm in the later novel Célestine's conviction that, like hereditary stigmas or diseases, "servitude is in the blood" and can never be wholly extirpated $(J F 272,382)$.

Locked into a carnivalesque ritual of parodic doubling, maid and mistress reproduce the master/slave dialectic as the stuff of high comedy. Which is the real maid, and which is the copy? When does the factotum become less than factitious, something more than ersatz master? The servant's text qualifies as a fetishistic genre in its grotesque simulation of the master's discourse, whereby it becomes a "secondhand" (in the sense of "already used," "handed down") master narrative. Though this genre may be seen as undermining the authority of such canonic works as Flaubert's Un Coeur simple or Freud's Case of the Wolf-man, it fails, in the end, to empower itself through representational strategies that are themselves free of false consciousness.

It is perhaps no surprise that the imbrication of political and psychoanalytical master/slave dialectics that one finds in Mirbeau's

54. Edmond and Jules de Goncourt, Germinie Lacerteux (Paris: Flammarion, 1930), pp. $130-31$. 
Le Journal d'une femme de chambre would appeal to a filmmaker such as Luis Bunuel. Though not the first to adapt the book for the screen-Jean Renoir had already done so in 1946 with an American production, The Diary of a Chambermaid, starring Paulette Goddard and Burgess Meredith-Bunuel's particular combination of realism and surrealism in Le Journal d'une femme de chambre (1963) afforded not just an original interpretation of the novel but also a form of filmic fetishism.

Transposing Célestine's confessional, loosely concatenated narrative into a seamless drama involving proto-Fascist politics (the action is moved up from 1900 to the late 1930s), a sex murder, and the ascendance of a chambermaid to bourgeois respectability as the wife of a provincial seigneur (in the movie, Célestine marries not Joseph but the Lanlaires' neighbor and rival, Captain Mauger), Buñuel plays down the disturbing complicity of Mirbeau's heroine. The foot fetishism episode is collapsed by Bunuel into the central diegesis, itself structured around Célestine's sojourn with the Lanlaires. In this scene, the art of the fetishistic close-up, the hyperrealistic frame that focuses in and concentrates relentlessly on the single image, recalls what Freud implied when he argued, "It seems that when the fetish comes to life, so to speak, some process has been suddenly interrupted." Wiggling and squirming on the screen, as if possessed of a life of their own, defamiliarized and uncannily detached from the leg as in surrealist collages, sculptures, or "picture-objects" (such as Miró's Poetic Object of 1936, which features a shoe-clad mannequin leg suspended over a bowler hat and crowned by a stuffed parrot, or Dali's 1931 Scatological Object Functioning Symbolically, depicting a large shoe placed beneath its miniaturized photographic replica), Buñuel's boots become obscene, a pair of animated phalluses. Images of perverse desire floating in space, of "suspense" both in the sense of physically suspended and emotionally fascinating, they approximate figures of what John Simon, evoking the myth of Tantalus, would call in a scathing review of Bunuel's later film, The Discreet Charm of the Bourgeoisie, "co-eatus interruptus."55 This expression seems oddly justified when it is remembered that Monsieur Rabour's nemesis is to die, literally, "with his foot in his mouth."

Interruption, one of the techniques of film editing, is instrumentalized as a form of fetishism throughout Buñuel's films. Like the

55. John Simon, "The Discreet Charm of the Bourgeoisie: Why Is the Co-eatus Always Interruptus?" in The World of Luis Buñuel: Essays in Criticism, ed. Joan Mellen (New York: Oxford University Press, 1978), p. 368. 
"coupeur de nattes" (pigtail cutter) who races through the case histories of Krafft-Ebing capturing the pigtails of unsuspecting schoolgirls (metonyms for the rest of the female anatomy according to Krafft-Ebing; their odor a source of coprophilic attraction according to Freud), Bunuel refines the art of découpage (cutting), deriving a special jouissance from the camera's fondling of a visually intransitive fragment. Barthes would query: "Is the tableau then (since it arises from a process of cutting out) a fetish-object?"56 Extending the discourse of Christian Metz on the role of framing, or encadrement, in the fundamentally "erotogenic" experience of film viewing, Barthes privileged the notion of cutting, as when he said of Eisenstein's Battleship Potemkin:

- The film is a contiguity of episodes, each one absolutely meaningful, aesthetically perfect, and the result is a cinema by vocation anthological, itself holding out to the fetishist, with dotted lines, the piece for him to cut out and take away to enjoy (isn't it said that in some cinemathèque or other a piece of film is missing from the copy of Battleship Potemkin-the scene with the baby's pram, of course-it having been cut off and stolen lovingly like a lock of hair, a glove or an item of women's underwear? ${ }^{57}$

By identifying the repertory of objects (on the order of Eisenstein's baby carriage) that are subject to découpage and close-up, one might construe Buñuel's personal vocabulary of castrated images, each of which bears the distinctive stamp of a fetish. Drawn from the culture of realist painting and fiction, Buñuel's visual icons point on the one hand to surrealism's parasitical relationship to realism and on the other to the familiar affinities between surrealism and fetishism. Both rely on the psychopathology of childhood memories cluttered with the bric-a-brac of the nursery, articles of clothing worn by the maid, curios of the bourgeois interior or idées reçues surrounding these items, as in Flaubert's entry for boots in his "Dictionnaire des idées reçues": "On n'est jamais chaussé qu'avec

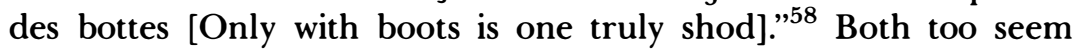
to have a common denominator in the psychoanalytics of vision, specifically a science or theory of "seeing in the dark," which Freud alluded to indirectly with the verb to scotomize (skotos in Greek means

56. Roland Barthes, "Diderot, Brecht, Eisenstein," Image-Music-Text, trans. Stephen Heath (New York: Hill and Wang, 1977), p. 71.

57. Ibid., p. 72.

58. Gustave Flaubert, Bouvard et Pécuchet (Paris: Garnier-Flammarion, 1966), p. $33^{8}$. 
"darkness"). Finally, both depend on the trope of metonymy as a way of increasing the legibility of desire.

The coupling of metonymy, as brutal montage of intimate artifacts, with magnification-the zoom-lens effect that distorts the miniature by transforming it into the gargantuan-might be seen as one of Buñuel's most distinctive contributions to the definition of filmic fetishism. In a macabre shot of the raped and murdered "little Claire," in Le Journal d'une femme de chambre, the camera travels along the spread-eagled legs of the girl (the rest of her body is blocked from view) and focuses obsessively on a viscous, phallic snail perched upon her knee. The snail, like the ants that swarm out of a woman's armpit or appear in the palm of a man's hand in Un Chien andalou, designates the fetish as indexical marker of the forbidden, of horror impossible to contemplate. With a splice, obstruction, distraction, substitute image, or any other technique of visual ellipsis or parataxis, Buñuel's camera obscures the "obscure object of desire" while at the same time disclosing its shadowy trace.

Here we are again reminded of that disturbing passage in Freud's essay on fetishism where he takes a painstaking detour in order to contradict an apparently gratuitous term applied by another psychoanalyst to the object or subject that Freud wishes to call repression. This term, scotomization, becomes, however, immediately less gratuitous when we realize that it refers to "dizziness, dimness of sight" or, more technically, to "an obscuration of part of the visual field due to lesion of the retina or of the ophthalmic center of the brain." 59 Imputing to the psychoanalyst Laforgue the notion that the fetishist scotomizes the perception of the woman's lack of a penis, Freud then goes on to repudiate the choice of this term: “'Scotomization' seems to me particularly unsuitable, for it suggests that the perception is entirely wiped out, so that the result is the same as when a visual impression falls on the blind spot on the retina. In the situation we are considering, on the contrary, we see that the perception has persisted, and that a very energetic action has been undertaken to maintain the disavowal." ${ }^{\circ}$ Freud's "correction" of Laforgue notwithstanding, his own preferred substitutes-“denial," "denegation" (Verdrängung, Verneinung)—carried, as we have seen, no comparable visual denotation. Had he recuperated the term more fully, revising it to include his own emphasis on partial disavowal,

59. Oxford English Dictionary, s.v. "scotomization."

6o. Freud, "Fetishism," Standard Edition 21:153-54. 
he might have afforded the basis for a definition of filmic fetishism-a "science of skotology"-situated mid-point between the eschatological (regressing to origins or infantile fixations) and the scatological (filthy, perverse, taboo). Within this scheme, the proper instrument of fetishistic vision would no longer be a camera but a skotoscope (which we could define as an instrument that enables its user to "see in the dark"), a machine that, by partially obscuring the visual field, literalizes the verbal metaphor of "a fly in the eye." ${ }^{\prime}$ Some such machine was no doubt behind Buñuel's first surrealist film-Un Chien andalou, an authentic piece of automatic writing in the dark-where an eye is hideously cut open with a razor, thus joining the motif of castrated vision to the architectural derivation of skotos (skotia), synonymous with groove or cut. Appropriately enough, this "cutting of the cut" (or montage) was most directly signaled by Buñuel's own treatment of Mirbeau's text, where an episode seemingly calculated in advance to appeal to a future surrealist is subjected itself to scotomization: Célestine's resigned cutting of the boot out of the mouth of Monsieur Rabour is curiously omitted from Buñuel's footage. Was Buñuel, like Freud, susceptible to suppression of the maid once she appeared fully exposed as maternal castrator?

Mirbeau's maid, Freud's maid, and now Buñuel's maid-each, eventually, seems doomed to negation and visual punishment. The screen "punishes" Célestine, much like the sadistic narrator in Robert Coover's Spanking the Maid, as he "cuts" brutally into the narrative of his own fantasies, splicing dissociated frames of the servant entering, exiting, or bending over in submission. The feminist film critic, Laura Mulvey, commenting on the broader issue of the filmic subjection of women, allows us to situate the sadistic treatment of Buñuel's Célestine in relation to the inherently sadistic voyeurism of the male gaze:

- Thus the woman as icon, displayed for the gaze and enjoyment of men, the active controllers of the look, always threatens to evoke the anxiety it originally signified. The male unconscious has two avenues of escape from this castration anxiety: preoccupation with the reenactment of the original trauma (investigating the woman, demystifying her mystery), counterbalanced by the devaluation, punishment, or saving of the guilty

61. See Hubert Damisch's explication of the "fly" in Valerio Adami's portrait of Freud as bait (appât), spot (tache), and signature, in Fenêtre jaune cadmium (Paris: Seuil, 1984), pp. 239-64. 
object... or else complete disavowal of castration by the substitution of a fetish object.... The first avenue, voyeurism,... has associations with sadism: pleasure lies in ascertaining guilt (immediately associated with castration), asserting control, and subjecting the guilty person through punishment or forgiveness. ${ }^{62}$

Mulvey illuminates the power of the maid as a dual sign: a fetish or cult object on the one hand, an object of visual abuse on the other. More important, by referring us back to the problem of scopic mastery (raised by Cixous, developed by Luce Irigaray), Mulvey enables us to read the maid as a symbolic representation of the potentially threatening female viewer, as a domestic spy who uncovers the insecurities of the master, surprising him in the privacy of unchecked fantasy. ${ }^{63} \mathrm{Or}$, as nineteenth-century tradition would have it, the maid, becoming herself the direct agent of fantasy's fulfillment, must be monitored by the phallic look, like the female figure on screen or the feminist film critic, and, if necessary, punished with filmic fustigation.

62. Laura Mulvey, "Visual Pleasure and Narrative Cinema," in Visual and Other Pleasures (Bloomington: Indiana University Press, 1989), pp. $21-22$.

63. In her important critique of Freudian phallocentrism, Luce Irigaray has challenged the preeminence of (male) scopic perversion, with its obsessive privileging of that phallic place. Summarizing the implications of her argument in Sexual/Textual Politics: Feminist Literary Theory (London: Methuen, 1985), Toril Moi notes: "Freud's own texts, particularly 'The uncanny, theorize the gaze as a phallic activity linked to the anal desire for sadistic mastery of the object. The specularizing philosopher is the potent master of his insight; as the example of Oedipus demonstrates, the fear of blindness is the fear of castration. As long as the master's 'scopophilia' (i.e., 'love of looking') remains satisfied, his domination is secure. No wonder then that the little girl's rien à voir ('nothing to be seen') is threatening to the male theorist" (p. 134). Subject to a nihilating gaze, covered with "blind spots" that obscure her from view, the maid's body, as a text, reveals an anxiety over scopic domination in master and theorist alike. 